Izvorni znanstveni članak Primljen: 9. svibnja 2021.

izv. prof. dr. sc. Vesna Kostović-Vranješ

Prihvaćen: 15. rujna 2021.

Filozofski fakultet Sveučilišta u Splitu

kostovic@ffst.hr

https://orcid.org/0000-0002-0161-9484

dr. sc. Mila Bulić, poslijedoktorandica

Filozofski fakultet Sveučilišta u Splitu

mbulic@ffst.hr

https://orcid.org/0000-0002-8090-897X

Viktorija Periša, mag. prim. educ.

OŠ „Vodice“

\title{
STAVOVI STUDENATA UČITELJSKOG STUDIJA I UČITELJA RAZREDNE NASTAVE O NASTAVI NA DALJINU
}

Sažetak: Prelazaks učioničke nastave na nastavu na daljinu u cijelom odgojno-obrazovnom sustavu Republike Hrvatske započeo 13. ožujka 2020. godine zbog pandemije novog zaraznog koronavirusa COVID-19. Navedeno je uvjetovalo nagli prelazak na nastavu na daljinu i niz poteškoća tijekom njene realizacije pa je stoga provedeno istraživanje kojem je cilj bio utvrditi stavove studenta, budućih učitelja razredne nastave, i učitelja praktičara o nastavi na daljinu u kojoj su sudjelovali. Rezultati provedenoga istraživanja pokazuju značajne razlike u percepciji prelaska s učioničke nastave na nastavu na daljinu koja je učiteljima praktičarima bila teža za organizirati i realizirati. Istraživanjem su utvrđeni stavovi o nastavi na daljinu te stavovi o nastavi na televiziji. Dobiveni rezultati istraživanja mogu poslužiti za unapređenje nastave na daljinu koja će se provoditi po potrebi izmjenjujući se s nastavom u učionici.

Ključne riječi: e-učenje, informacijska i komunikacijska tehnologija, nastava na televiziji, nastava na daljinu, nastava prirode i društva. 


\section{UVOD}

Za suvremene učenike često kažemo da su pripadnici always online generacije, koja želi i očekuje uključivanje informacijske i komunikacijske tehnologije (u nastavku IKT) u odgojno-obrazovni proces (Bulić i Novoselić, 2016). To daje obavezu učiteljima proširivati svoje kompetencije, uključujući digitalnu, jer u suvremenoj nastavi gotovo da i nema nastavnog sata na kojem se ne koristi IKT. Digitalno kompetentan učitelj trebao bi znati djelovati u digitalnom okruženju, biti informacijski pismen (Nadrljanski, 2006, str. 262-263) i pripremljen za cjeloživotno učenje. S obzirom na to da je danas internet glavni medij kojim se prenose informacije, digitalno kompetentan učitelj do informacija potrebnih za unapređenje nastave dolazi upravo putem njega. Kako bi učitelji mogli procijeniti koje su im digitalne kompetencije potrebne, izrađen je 2017. godine Europski okvir digitalnih kompetencija za učitelje. Osnovne kompetencije podijeljene su u šest područja, koja obuhvaćaju različite aspekte profesionalnih aktivnosti: profesionalni angažman, digitalni izvori i materijali, učenje i poučavanje, praćenje i vrednovanje, osnaživanje učenika te omogućavanje razvoja i usmjeravanje digitalnih kompetencija učenika (CARNet, 2020).U skladu s razvojem digitalizacije, svi udžbenici prirode i društva imaju svoju digitalnu inačicu, koju na satu koriste učitelj i učenici koji e-sadržajima mogu pristupati i od kuće. Upravo zato je danas, više nego ikad, nužno cjeloživotno učenje i profesionalno usavršavanje stručnih kompetencija učitelja. Stoga je neophodno tijekom inicijalnog obrazovanja budućih učitelja i kod učitelja primarnoga obrazovanja razviti temeljnu digitalnu kompetenciju za primjenu IKT-a u obrazovne svrhe.

Potpuno online nastava može biti od izuzetne pomoći u situacijama bolesti učenika ili drugih opravdanih izostanaka kada ne može nazočiti nastavi u učionici. Upravo je zdravstveno epidemiološka situacija u kojoj se zatekao svijet u proljeće 2020. godine dovela do toga da je većina država u vrlo kratkom vremenu trebala prijeći na online nastavu i nastavu na daljinu. Primjena nastave na daljinu podrazumijeva kvalitetno oblikovanje nastavnih sadržaja koji se postavljaju na e-platformu te osmišljavanje raznovrsnih i kreativnih aktivnosti koji će biti poticajni za izvršenje postavljenih zadaća. Tijekom procesa učenja izuzetno je važno redovito praćenje aktivnosti učenika, davanje povratne informacije o radu i domaćim zadaćama, predlaganje aktivnosti za daljnji napredak te ocjenjivanje ostvarenosti potrebnih ishoda učenja.

\section{PRIRODOSLOVNO PODRUČJE}

Nacionalni okvirni kurikulum (NOK, 2010) definirao je prirodoslovno područje kao cjelinu koja se temelji na spoznajama prirodnih znanosti: biologije, kemije, fizike, geofizike i geologije. Glavni cilj učenja i poučavanja prirodoslovlja jest razvijanje prirodoznanstvene pismenosti koja podrazumijeva da 
učenik upotrebljava znanstvene koncepte, metode i postupke za rješavanje problema i donošenje odluka u svakodnevnome životu te cjeloživotnim učenjem odgovara na nove izazove. Promatrajući cijelu vertikalu odgojno-obrazovnog sustava može se vidjeti kako osnove prirodoslovne kompetencije temelj imaju u programima nastavnog predmeta Priroda i društvo u prvom i drugom obrazovnom ciklusu, a nastavljaju kroz nastavne predmete Priroda i Geografija u predmetnoj nastavi 5. i 6. razreda te nastavne predmete Biologija, Kemija, Fizika i Geografija od 7. razreda. Prirodne znanosti bitne su za napredak svakoga društva te je potrebno ulagati poseban napor za razvoj prirodoslovne pismenosti učenika od najranije dobi što ukazuje na važnost nastave prirode i društva.

Nastavni predmet Priroda i društvo, kao sastavni dio prirodoslovnoga područja, ima cilj poticati i upotpunjavati spoznaje o značajkama, strukturama, funkciji, raznolikosti, rasprostranjenosti, međusobnoj povezanosti i promjenjivosti živog svijeta. Priroda i društvo se temelji na interdisciplinarnosti, povezivanju i objedinjavanju znanstvenih saznanja prirodoslovnoga, društvenohumanističkoga i tehničko-informatičkoga područja (Kurikulum nastavnoga predmeta Priroda i društvo za osnovne škole, 2019). Odgojno-obrazovni ciljevi Prirode i društva ostvaruju se kroz četiri ključna međusobno povezana koncepta: Organiziranost svijeta oko nas, Promjene i odnosi, Energija te Pojedinac i društvo. Navedeni koncepti, povezani su s definiranim međupredmetnim temama kao i ostalim nastavnim predmetima prvoga obrazovnoga ciklusa, a u svakome od koncepata značajno mjesto zauzima istraživački pristup temeljen na opažanju, zaključivanju, raščlambi, sintezi te razvijanju kreativnosti i kritičkog mišljenja (Kurikulum nastavnoga predmeta Priroda i društvo za osnovne škole, 2019). Kako bi se ostvarili ishodi učenja i postigao cjeloviti razvoj učenika stavljenih u središte odgojno-obrazovnoga procesa, zadatak je učitelja organizirati nastavu koja uključuje različite izvore znanja, sredstva, pomagala, metode, tehnike i strategije poučavanja. Upravo primjena različitih strategija poučavanja utječe kod učenika na razvoj interesa za nastavu i na povećanje motivacije za učenje sadržaja predmeta koji se uči Boras (2009).

\section{IKT I NASTAVA NA DALJINU}

Primjena IKT-a svakim danom sve više utječe na sva područja života ljudi pa tako i na odgoj i obrazovanje. Osim što potiče stjecanje vještina, IKT služi i za cjeloživotno učenje, a svakim danom otvara nove mogućnosti i perspektive u procesu odgoja i obrazovanja (Hutinski i Aurer, 2009). Prema KostovićVranješ (2015, str. 67) „Informacijska i komunikacijska tehnologija uključuje različite tehnološke alate i resurse koji se upotrebljavaju kako za komunikaciju, tako i za stvaranje, pohranjivanje i upravljanje informacijama pa je stoga ona jedan od temeljnih građevnih blokova suvremenog obrazovanja." Mogućnosti primjene IKT-a u nastavi su mnogobrojne, a kako bi obogatili i osuvremenili 
nastavu, učinili ju zanimljivijom i aktivirali učenike, učitelji se mogu koristiti različitim tehnologijama i digitalnim alatima: multimedijalnima, alatima za komunikaciju i suradnju, digitalnim udžbenicima, obrazovnim platformama, sustavima za upravljanje učenjem, digitalnim kvizovima, društvenim mrežama, videokonferencijama, mobilnim učenjem i slično. Kod odabira tehnologija, učitelj na umu treba imati dob učenika i specifičnosti nastavnih sadržaja koji se obrađuju.

Primjena IKT-a omogućava raznolikost u isporuci nastavnih sadržaja i komunikaciji onih koji sudjeluju u odgojno-obrazovnom procesu, a učenici putem računalnih sadržaja mogu usvajati ishode učenja na njima blizak način (Bulić i sur., 2017). Danas veliku ulogu tijekom primjene IKT-a ima internet, kao alat koji omogućuje brzu razmjenu informacija, slike, teksta, zvuka, videozapisa i sl. Prilikom implementacije IKT-a valja imati na umu kako ona nije sama sebi svrha, već je potrebno kritički promisliti o razlozima implementacije, ishodima učenja kao i didaktičkom oblikovanju u svrhu poboljšanja nastavnoga procesa (Pejić Papak i Grubišić Krmpotić, 2016). Međupredmetna tema Uporaba IKT-a ostvaruje se u svim nastavnim predmetima, a ukazuje kako se učenjem i poučavanjem uz pomoć računala i ostalih digitalnih uređaja potiče se razvoj znanja, vještina i stavova povezanih s uporabom IKT-a, a učenici se svrsishodno i odgovorno koriste IKT-om, istražuju, komuniciraju, surađuju i stvaraju u digitalnome okruženju (Kurikulum međupredmetne teme Uporaba Informacijske i komunikacijske tehnologije za osnovne i srednje škole, 2019). Korištenje IKTom traži i razvoj samoodgovornosti učenika, naročito ako domaće zadaće predaju u e-obliku i imaju točno zadano vrijeme predaje (Bulić i Kostović-Vranješ, 2019).

Tinio (2003) naglašava da se IKT tehnologije i alati u kojima se kombinira tekst, zvuk i slike mogu koristiti za pružanje izazovnih i autentičnih sadržaja koji će učenike uključiti u proces učenja. Implementacijom IKT-a u proces učenja ubrzava se pristup informacijama, postiže se interaktivnost te se pruža mogućnost samostalnog i personaliziranog učenja (Ćukušić i Jadrić, 2012). Zbog lakšeg razumijevanja podjele oblika nastave obzirom na implementaciju IKT-a u nastavnome procesu s naglaskom na udio isporuke nastavnih sadržaja putem interneta (online), u nastavku je prikazana prilagođena tablica (Tablica 1.) Allen i Seamana (2013). Iz prikazane je tablice vidljivo da autori Allen i Seaman (2013) obzirom na implementaciju IKT-a i isporuku nastavnih sadržaja putem interneta, nastavu dijele na: tradicionalnu nastavu, nastavu potpomognutu Webom, hibridnu nastavu i online nastavu. Tradicionalna nastava je nastava u učionici, usmjerena na učitelja i nastavne sadržaje. U ovome obliku nastave učenik je uglavnom pasivan i njegova je uloga pasivna, slušalačka. Iako se u tradicionalnoj nastavi online tehnologije ne koriste, učitelji mogu koristiti tehnologiju bez korištenja interneta, računalo i projektor. 
Tablica 1.Oblici nastave obzirom na implementaciju IKT-a i isporuku nastavnih sadržaja online (prema Allen i Seaman, 2013)

\begin{tabular}{|c|c|c|}
\hline $\begin{array}{l}\text { Udio isporuke } \\
\text { online sadržaja }\end{array}$ & Oblik nastave & Opis \\
\hline $0 \%$ & $\begin{array}{l}\text { tradicionalna } \\
\text { nastava (nastava } \\
\text { licem } \mathrm{u} \text { lice) }\end{array}$ & $\begin{array}{l}\text { Nastava se odvija u učionici, online } \\
\text { tehnologije se ne koriste. }\end{array}$ \\
\hline $1 \%$ do $29 \%$ & $\begin{array}{l}\text { nastava } \\
\text { potpomognuta } \\
\text { Webom }\end{array}$ & $\begin{array}{l}\text { Tehnologija se koristi u svrhu poboljšanja } \\
\text { tradicionalne nastave. Učitelj na } W e b \\
\text { stranicama kolegija postavlja sadržaje } \\
\text { za učenje, koristi se } W e b \text { sadržajima na } \\
\text { nastavi . Učitelj se koristi e-mailom za } \\
\text { komunikaciju s učenicima. }\end{array}$ \\
\hline $30 \%$ do $79 \%$ & hibridna nastava & $\begin{array}{l}\text { Nastava predstavlja kombinaciju nastave } \\
\text { u učionici i online nastave. Veliki udio } \\
\text { nastavnih sadržaja se isporučuje online. } \\
\text { Za isporuku se često koriste LMS sustavi } \\
\text { (Learning Management Systems) odnosno } \\
\text { sustavi za upravljanje učenjem. }\end{array}$ \\
\hline 80 \% i više & online nastava & $\begin{array}{l}\text { Nastavni sadržaji se uglavnom isporučuju } \\
\text { online. (najčešće pomoću LMS-a). Obično } \\
\text { nema nastave licem u lice. }\end{array}$ \\
\hline
\end{tabular}

Računalo učitelji mogu koristiti za pripremu nastave, primjerice izradu pripreme za nastavni sat u Wordu, a računalo i projektor kao pomoć u prezentiranju nastavnih sadržaja putem npr. PowerPoint prezentacije. Navedeni je oblik nastave najčešći, ali nije svrhovit jer učenik do spoznaja ne dolazi vlastitom aktivnosti. Odmak od tradicionalne nastave predstavlja nastava potpomognuta Webom. Učitelj na raspolaganju ima bezbroj internetskih izvora, alata i tehnologija kojima se može koristiti izravno na nastavi, ali i poslije nastave u svrhu komunikacije, suradnje, aktiviranja i uključivanja učenika u nastavni proces. U hibridnoj se nastavi spajaju tradicionalna nastava i online nastava uz pomoć IKT-a. Učenici uče i u školi i kod kuće, a kroz ovaj se oblik nastave potiče njihova aktivnost i samostalan rad dok dostupnost nastavnih sadržaja olakšava učenje i planiranje istoga. U online nastavi proces učenja i poučavanja se uglavnom odvija u potpunosti online. $\mathrm{U}$ ovome se obliku nastave često koriste sustavi za upravljanje učenjem preko kojih se odvija komunikacija, isporuka nastavnih sadržaja, suradnja, vrednovanje i slično. Uspješnost ovakvoga oblika nastave najviše ovisi o učeniku, njegovoj motivaciji, odgovornosti i aktivnosti.

Učenje na daljinu (engl. distance learning) oblik je obrazovanja čiji se početci vežu za 19. stoljeće (Zenović i Bagarić, 2014), a u svojim je početcima bilo je usmjereno na netradicionalne studente; vojnike, radnike s punim radnim 
vremenom i geografski udaljene pojedince koji nisu mogli pohađati nastavu u učionicama (Simonson i Berg, 2016). Zenović i Bagarić (2014) kao grupe kojima je bilo namijenjeno učenje na daljinu ističu i žene koje tada nisu imale adekvatan pristup obrazovnim sadržajima. Prije razvoja digitalnih i elektroničkih tehnologija, medij koji je spajao studente/polaznike i nastavnike/mentore bila je pošta. Razvojem tehnologija došlo je i do promjene medija, najprije radija pa zatim televizije.

U današnje se vrijeme učenje na daljinu odnosi na učenje i poučavanje online, u ,virtualnim učionicama“, temeljeno na internetu, a često zvano e-učenje. Obzirom na tehnološke promjene, ovisno o vremenu, može se zaključiti da se učenje na daljinu temelji na korištenju trenutno dostupnih tehnologija za razmjenu informacija (Jukić, 2017). Danas se učenje na daljinu zasniva na internetu, a Budić i Hak (2014, str. 3) ga definiraju elementima:

- „vremenskom i prostornom razdvojenošću nastavnika i studenta tijekom dužeg dijela obrazovnog procesa,

- korištenjem obrazovnog medija (najčešće Internet) u svrhu povezivanja nastavnika i studenta i u svrhu prezentiranja obrazovnog sadržaja,

- osiguravanjem dvosmjerne komunikacije nastavnika i studenta,

- naglaskom na kontroli procesa usvajanja nastavnih sadržaja, prvenstveno od strane studenta."

Temeljne prednosti ovakva oblika nastave u odnosu na tradicionalnu nastavu u učionici su: individualizacija nastave koja omogućava napredovanje učenika vlastitim tempom, učenici su u čestom kontaktu s izvorima informacija čime se povećava njihova aktivnost, umjesto ljudi putuju informacije čime se smanjuju troškovi. Iako nastava na daljinu ima svojih prednosti postoje i određeni nedostaci (Bulić, 2018). Prema Kalamković i sur. (2013) nedostaci učenja na daljinu su: nedostatak fizičkoga kontakta među sudionicima obrazovnoga procesa, preduvjet da svi studenti moraju na raspolaganju imati odgovarajuću tehnologiju (računalo, internetsku vezu), zahtjevnost potrebne tehnologije (npr. videokonferencije). Nedostatak se ogleda i u visokom postotku odustajanja od ovakva oblika obrazovanja zbog nedostatka ustrajnosti ili sposobnosti studenata, a zbog same fizičke izoliranosti potreban je visok stupanj aktivnosti i samodiscipline (Zenović i Bagarić, 2014). Navedeno se može nadopuniti rezultatima istraživanja autora Gökbulut (2020) koje se temeljilo na intervjuima fokus grupa, 27 turskih studenata koji se obrazuju na daljinu. Studenti su kao nedostatke naveli nedostatak interakcije između nastavnika i studenta, razlike u metodama poučavanja (neki nastavnici samo čitaju sa slajdova, lekcije nisu interaktivne). Kao prednosti, studenti su pak izdvojili lak pristup nastavnim materijalima, mogućnost ponovnoga gledanja snimljenih predavanja i uštedu vremena. Iz svega navedenog uočava se kako je za uspješnost učenja na daljinu potrebna suradnja i sustavni rad svih sudionika takvoga oblika nastave (Bulić, 2018). Primarna uloga učenika je kao i kod tradicionalne nastave dolaženje 
do novih spoznaja koje zahtjeva motivaciju, planiranje te sposobnost analize i primjene nastavnih sadržaja. Uloga nastavnika temelji se na razumijevanju potreba i karakteristika učenika u situaciji ograničenoga ili nikakvoga kontakta licem u lice, prilagodbi stila predavanja i uspješnoga funkcioniranja u ovakvome obliku nastave povezanoga s razumijevanjem tehnologije. Iako je za kvalitetno izvođenje nastave na daljinu važno razumjeti tehnologiju, Anetta i Shymanski (2008) ističu da nastavnici prečesto nisu osposobljeni za učinkovitu uporabu dostupnih tehnologija te stoga pri oblikovanju nastavnih sadržaja ne iskorištavaju prednosti istih.

Prema Li i sur. (2017) čimbenici koji utječu na stavove nastavnika o online nastavi na daljinu su motivacija i iskustvo izvođenja takve nastave. Rezultati istraživanja Allena i sur. (2012) pokazali su da nastavnici koji su imali iskustva s izvođenjem online nastave imaju pozitivnije stavove o online nastavi u odnosu na nastavnike koji ga nisu imali, te smatraju da može biti podjednako učinkovita kao nastava licem u lice.

Početci nastave na daljinu u suvremenoj hrvatskoj povijesti sežu u 1991. godinu kada je bila organizirana Ratna TV škola. To je bio posebni obrazovni program Hrvatske televizije pokrenut zbog rata koji se tada vodio u Republici Hrvatskoj (u nastavku: RH).

Novi prelazak s nastave u učionici na nastavu na daljinu u svim osnovnim i srednjim školama kao i u visokom obrazovanju započeo je Odlukom Vlade RH donesenom 13. ožujka 2020. godine do koje je došlo zbog pandemije novog zaraznog koronavirusa COVID-19. Suradnjom Ministarstva znanosti i obrazovanja (u daljnjem tekstu: MZO) i Hrvatske radiotelevizije (u daljnjem tekstu: HRT) organizirana je, prema važećem kurikulumu i nastavnom planu, nastava za učenike razredne nastave na trećem programu pod nazivom Škola na trećem. Za učenike viših razreda osnovne škole organizirana je nastava na Sportskoj televiziji u obliku videolekcija i online, dok je za učenike srednjih škola 23. ožujka organizirana nastava $u$ istim oblicima putem RTL2 programa (Ministarstvo znanosti i obrazovanja, 2020). Raspored održavanja nastavnih sati objavljivan je na stranicama Škole za život, MZO-a i Hrvatske akademske istraživačke mreže (u daljnjem tekstu: CARNet). Nastava za učenike razredne nastave na Školi na trećem prikazivala se u jutarnjem terminu u trajanju od jednoga sata s prosječnim trajanjem jednoga nastavnoga predmeta od $15 \mathrm{mi}-$ nuta. Reprizno emitiranje se odvijalo u poslijepodnevnim satima, a učenici su nastavu mogli pratiti i putem YouTube mrežne usluge. Učenici oštećena sluha su Školu na trećem mogli pratiti putem Facebook stranice Hrvatskog društva prevoditelja znakovnog jezika. Ravnatelji škola su se trebali uključiti u „virtualnu učionicu“ "na sustavu Loomen zbog razmjene informacija i praćenja obavijesti te organizirati „,virtualnu zbornicu“. Nastavnici u predmetnoj nastavi kao i srednjoškolski nastavnici organizirali su „virtualni razred“ u jednom od sustava za komunikaciju, učenje i suradnju (Moodle, Yammer, Teams i sl.). Učiteljima 
razredne nastave predloženo je povezivanje s roditeljima u virtualnu grupu putem komunikacijskih kanala (Viber, WhatsApp, e-mail, Facebook i sl.) kao i slanje dodatnih zadataka učenicima vezanima uz nastavne sadržaje putem roditelja (Ministarstvo znanosti i obrazovanja, 2020). Nakon što bi učenici u svojim domovima pratili nastavu na televiziji dobili bi zadatke od svojih učitelja koje su rješavali kao domaće zadaće te su ih ponovo dogovorenim kanalima vraćali učiteljima koji su ih vrednovali. Što se tiče vrednovanja i ocjenjivanja, veoma zahtjevnih procesa u nastavi na daljinu, objavljene su upute za provođenje istih u virtualnom okruženju. Učeničku aktivnost moguće je pratiti putem domaćih zadaća (Bulić i Kostović-Vranješ, 2019), samostalnih istraživanja ili suradničkog učenja, a formativno i sumativno vrednovanje može se provoditi kroz diskusije, testove, didaktičke igre, kvizove, zadaće, portfolije, istraživačke radove, prezentacije i sl. Vrednovanje i ocjenjivanje u razrednoj nastavi obzirom na dob učenika i komuniciranje posredstvom roditelja ima svojih specifičnosti. Za razrednu je nastavu bilo preporučeno praćenje aktivnosti učenika kroz izradu domaćih zadaća i vježbi te izradu umnih mapa, crteža, sastavaka, plakata i slično. Naglašeno je i da učenike razredne nastave ne treba usmeno ispitivati tijekom ovakvoga oblika nastave (Ministarstvo znanosti i obrazovanja, 2020).

Tijekom pandemije sva nastava učenika razredne nastave odvijala se na daljinu i to posredstvom televizije, pa shodno tome i nastava prirode i društva koja je bila u centru interesa provedenog istraživanja. Učitelji su, ako i njihovi učenici, pratili nastavu na televiziji, te su im nakon nastave prirode i društva slali odgovarajuće domaće zadaće. Studenti Učiteljskog studija Filozofskog fakulteta u Splitu imali su online nastavu iz svih kolegija te su u istraživanju iznijeli vlastite stavove o nastavi na daljinu. Uz redovnu online nastavu, studenti su imali i dodatni zadatak pratiti nastavu prirode i društva koja je bila organizirana na televiziji tijekom Škole na trećem, a sve u sklopu kolegija Metodika nastave prirode i društva.

Cilj istraživanja bio je utvrditi razlikuju li se učitelji i studenti Učiteljskog studija u stavovima prema nastavi na daljinu te u sudjelovanju i radu tijekom nastave na daljinu. U skladu s ciljem istraživanja, formirane su nul hipoteze istraživanja:

H1 Ne postoji statistički značajna razlika u težini prelaska s redovne nastave na nastavu na daljinu između učitelja i studenata Učiteljskog studija.

H2 Ne postoji statistički značajna razlika u tjednom vremenu za pripremanje nastave na daljinu u odnosu na redovnu nastavu između učitelja i studenata Učiteljskog studija.

H3 Ne postoji statistički značajna razlika u edukaciji za primjenu i korištenje digitalnih alata između učitelja i studenata Učiteljskog studija. 
H4 Ne postoji statistički značajna razlika u percipiranju važnosti tehničke podrške tijekom nastave na daljinu između učitelja i studenata Učiteljskog studija.

H5 Ne postoji statistički značajna razlika u stavovima prema nastavi prirode i društva na televiziji između učitelja i studenata Učiteljskog studija.

Prve četiri postavljene hipoteze odnose se na percepciju učitelja i studenata općenito o nastavi na daljinu, a peta se hipoteza odnosi na nastavu prirode $\mathrm{i}$ društva koja je bila organizirana na televiziji.

\section{METODOLOGIJA}

\section{UZORAK ISPITANIKA}

U istraživanju je sudjelovalo 329 ispitanika. Dio ispitanika čine učitelji razredne nastave $(\mathrm{N}=267)$, a dio studenti $(\mathrm{N}=62)$ četvrte i pete godine Filozofskog fakulteta u Splitu, smjer Učiteljski studij. Učitelji koji su sudjelovali u istraživanju rade na području više županija Republike Hrvatske (slika 1). Najveći postotak učitelja je iz Splitsko-dalmatinske županije (28,8 \%).

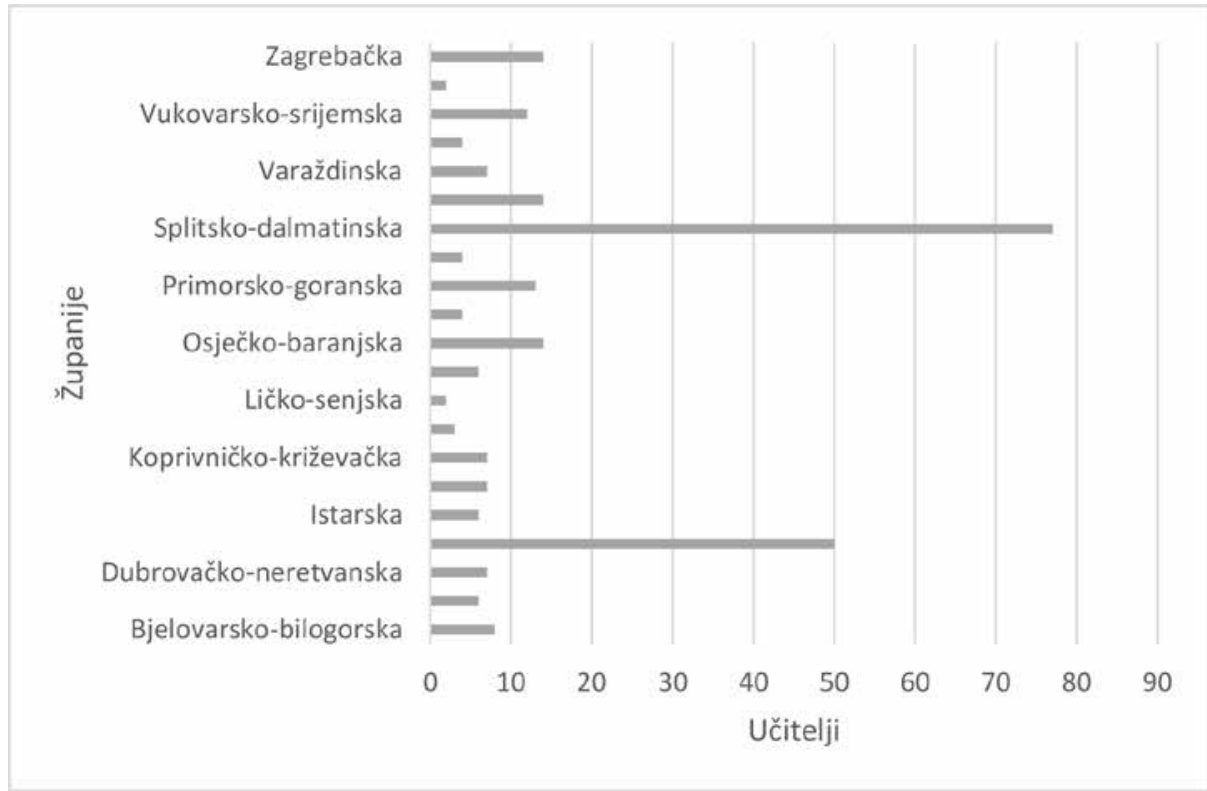

Slika 1. Uzorak ispitanih učitelja s obzirom na županije

Od ukupnog broja ispitanih učitelja 95,9 \% $(\mathrm{N}=256)$ čine učiteljice, a $4,1 \%(\mathrm{~N}=11)$ učitelji. Većina učitelja koji su sudjelovali u istraživanju radi u gradskim školama $(65,9 \%$ ), a 34,1 \% radi u seoskim školama. Promatrajući 
učitelje obzirom na napredovanje u zvanju, učitelja je 75,3\%, mentora 12,7 $\%$ i savjetnika $12 \%$. Do pet godina radnoga staža ima $15,7 \%(\mathrm{~N}=42)$ ispitanika, dok 34,8 \% (N = 93) ima od 6 do 15 godina radnoga staža, 26,6 \% $(\mathrm{N}=$ $71)$ od 16 do 25 godina radnoga staža, a $22,8 \%$ učitelja $(\mathrm{N}=61)$ ima 26 i više godina radnoga staža. Uzorak učitelja razredne nastave činili su učitelji koji su popunili anonimnu online anketu. Učitelji razredne nastave predaju, uz ostale nastavne predmete, prirodu i društvo pa su svi oni koji su odabrali popuniti anketu sudjelovali u istraživanju.

Kako su istraživanjem ispitivani i stavovi studenata, u istraživanju su sudjelovala i 62 studenta. Većinu ispitanih studenata čine studentice $(96,8 \%$ ), a studenti čine tek 3,2 \% uzorka. Studenata četvrte godine bilo je $41,9 \%(\mathrm{~N}=$ $26)$, a studenata pete godine bilo je $58,1 \%(\mathrm{~N}=36)$. Uzorak ispitanika-studenata namjerno je odabrana skupina četvrte i pete godine Učiteljskog studija Filozofskog fakulteta u Splitu jer su samo oni imali zadatak pratiti nastavu prirode i društva na televiziji tijekom Škole na trećem u sklopu kolegija Metodika nastave prirode i društva.

\section{UZORAK INSTRUMENATA}

Za potrebe istraživanja izrađena su dva anketna upitnika, jedan za učitelje razredne nastave (A1) i jedan za studente četvrte i pete godine Filozofskog fakulteta u Splitu, smjer Učiteljski studij (A2). Oba anketna upitnika u prvom dijelu ispituju socio-demografska obilježja ispitanika, a ostatak upitnika se odnosi na niz tvrdnji i slaganje s njima.

Anketni upitnik za učitelje (A1) u prvom je dijelu ispitivao sociodemografska obilježja ispitanika: županija u kojoj rade, spol, mjesto rada (selo/ grad), zvanje, broj godina radnoga staža, broj sati u pripremi i realizaciji nastave na daljinu te postojanje dosadašnjeg iskustva rada u nastavi na daljinu. Drugi dio upitnika sastojao se od 33 čestice zatvorenog tipa na koje su učitelji odgovarali korištenjem Likertove pet stupanjske skale $(1-u$ potpunosti se ne slažem, 2 - uglavnom se ne slažem, 3 - niti se slažem niti ne slažem, 4 uglavnom se slažem, 5 - u potpunosti se slažem) kojima se ispitivao stav, odnosno stupanj slaganja s navedenim tvrdnjama. Četiri pitanja na kraju anketnog upitnika bila su otvorenoga tipa. Učitelji su mogli napisati što smatraju prednošću nastave na daljinu, a što smatraju nedostatkom iste. Zadnja dva pitanja odnosila su se na nastavu prirode i društva koja je bila organizirana na televiziji te su navodili što smatraju prednošću nastave prirode i društva organizirane na televiziji, a što smatraju nedostatkom nastave prirode i društva na televiziji.

Anketni upitnik za studente sastojao se od tri dijela. Prvi dio upitnika obuhvaća socio-demografske podatke o ispitanicima: županija, spol, godina studija. Drugi dio upitnika sastojao se od 26 čestica/tvrdnji zatvorenog tipa na koje su studenti odgovarali korištenjem Likertove pet stupanjske skale $(1-\mathrm{u}$ 
potpunosti se ne slažem, 2 - uglavnom se ne slažem, 3 - niti se slažem niti ne slažem, 4 - uglavnom se slažem, 5 - u potpunosti se slažem) kojima se ispitivao stav odnosno stupanj slaganja s navedenim tvrdnjama o nastavi na daljinu na fakultetu. Četiri pitanja u upitniku bila su otvorenoga tipa: što ispitani studenti smatraju prednošću nastave na daljinu, što smatraju nedostatkom nastave na daljinu, što smatraju prednošću nastave prirode i društva organizirane na televiziji te što smatraju nedostatkom nastave prirode i društva na televiziji. Svi ispitanici ispunjavali su upitnik dobrovoljno i anonimno te su upoznati s ciljem provedbe istraživanja. Anketni su upitnik ispitani učitelji i studenti ispunjavali online. Istraživanje je provedeno u svibnju 2020., a trajalo je 15 dana.

\section{METODE OBRADE PODATAKA}

Za sve podatke su izračunati parametri deskriptivne statistike: aritmetička sredina, standardna devijacija, medijan, minimum, maksimum, koeficijent varijacije, koeficijent asimetričnosti i koeficijent spljoštenosti. Normalitet podataka je provjeren Kolmogorov-Smirnovljevim testom te je utvrđeno da rezultati ne odstupaju značajno od normalne distribucije. Korištenjem t-testa za nezavisne uzorke ispitana je statistička značajnost razlika u aritmetičkim sredinama odgovora ispitanika te su time ispitane hipoteze. Rezultati su smatrani signifikantnim ako je $p<0,05$. Svi rezultati izračunati su pomoću softvera Statistica 13.1.

\section{REZULTATI I RASPRAVA}

U istraživanju stavova učitelja razredne nastave i studenta Učiteljskog studija prema nastavi na daljinu, u kojoj su sudjelovali, korištene su ankete A1 i A2. U tablici 2 nalaze se rezultati deskriptivne statistike za istovjetne čestice anketa A1 (za učitelje) i A2 (za studente).

Iz tablice 2 vidljivo je kako učitelji iskazuju veće slaganje $s$ tvrdnjom o težini prelaska s redovne nastave na nastavu na daljinu u odnosu na studente odnosno učitelji percipiraju prelazak s redovne nastave na nastavu na daljinu težim nego studenti. Najmanja vrijednost, odnosno minimum za ovu varijablu iznosi 1.00 (uglavnom se ne slažem), što znači kako postoje učitelji i studenti koji ne procjenjuju prelazak na nastavu na daljinu teškim. Najveća vrijednost odnosno maksimum iznosi 5.00 (u potpunosti se slažem) i to kod obje skupine ispitanika što ukazuje kako i kod učitelja i studenata postoje oni kojima je prelazak bio u potpunosti težak.

Učitelji trebaju više vremena tjedno za pripremanje nastave na daljinu u odnosu na redovnu nastavu nego studenti. I u ovoj varijabli minimum kod obje skupine ispitanika je 1,00, a maksimum 5,00. 
Tablica 2. Rezultati deskriptivne statistike za čestice anketa A1 i A2 u kojima se uspoređuju studenti i učitelji (AS-aritmetička sredina; med-medijan; min-minimalna vrijednost; max-maksimalna vrijednost; SD-standardna devijacija; V-koeficijent varijabilnosti)

\begin{tabular}{|c|c|c|c|c|c|c|c|}
\hline Varijable & Ispitanici & AS & med & $\min$ & $\max$ & SD & $\mathbf{V}$ \\
\hline $\begin{array}{l}\text { Prelazak s redovne } \\
\text { nastave na nastavu na }\end{array}$ & Student & 2,56 & 2,00 & 1,00 & 5,00 & 1,17 & 45,6 \\
\hline daljinu bio mi je težak. & Učitelj & 3,31 & 3,00 & 1,00 & 5,00 & 1,30 & 39,3 \\
\hline $\begin{array}{c}\text { Potrebno mi je više } \\
\text { vremena tjedno u } \\
\text { pripremi za nastavu }\end{array}$ & Student & 3,98 & 4,00 & 1,00 & 5,00 & 1,11 & 27,8 \\
\hline $\begin{array}{l}\text { na daljinu u odnosu na } \\
\text { redovnu nastavu. }\end{array}$ & Učitelj & 4,22 & 5,00 & 1,00 & 5,00 & 1,15 & 27,2 \\
\hline \multirow{2}{*}{$\begin{array}{l}\text { Za kvalitetno odvijanje } \\
\text { nastave na daljinu bitna } \\
\text { je dobra internetska } \\
\text { veza. }\end{array}$} & Student & 4,77 & 5,00 & 3,00 & 5,00 & 0,49 & 10,3 \\
\hline & Učitelj & 4,49 & 5,00 & 1,00 & 5,00 & 0,98 & 21,9 \\
\hline \multirow{2}{*}{$\begin{array}{l}\text { Tijekom nastave na } \\
\text { daljinu javljaju se } \\
\text { tehnički problemi. }\end{array}$} & Student & 4,18 & 4,00 & 2,00 & 5,00 & 0,95 & 22,7 \\
\hline & Učitelj & 3,69 & 4,00 & 1,00 & 5,00 & 1,20 & 32,4 \\
\hline $\begin{array}{l}\text { Uvođenjem nastave na } \\
\text { daljinu samostalno sam } \\
\text { se educirala/educirao }\end{array}$ & Student & 4,08 & 4,00 & 1,00 & 5,00 & 0,91 & 22,3 \\
\hline $\begin{array}{l}\text { o korištenju i primjeni } \\
\text { različitih digitalnih } \\
\text { alata. }\end{array}$ & Učitelj & 4,32 & 5,00 & 1,00 & 5,00 & 1,09 & 25,1 \\
\hline \multirow{2}{*}{$\begin{array}{l}\text { Nastava prirode i } \\
\text { društva organizirana na } \\
\text { televiziji je odlična. }\end{array}$} & Student & 2,97 & 3,00 & 1,00 & 4,00 & 0,89 & 29,9 \\
\hline & Učitelj & 2,64 & 3,00 & 1,00 & 5,00 & 1,12 & 42,5 \\
\hline
\end{tabular}

Učitelji su se samostalno educirali kako bi u nastavi mogli primjenjivati razne digitalne alate te iskazuju veće slaganje s tvrdnjom o samostalnom educiranju o korištenju i primjeni različitih digitalnih alata uvođenjem nastave na daljinu u odnosu na studente. Studenti više procjenjuju kako je za kvalitetno odvijanje nastave na daljinu bitna dobra internetska veza nego učitelji. Također oni više uočavaju pojavljivanje tehničkih problema u odnosu na učitelje. Promatrajući nastavu na daljinu, organiziranu od strane Ministarstva znanosti i 
obrazovanja na javnoj televiziji, obje skupine ispitanika iskazuju osrednje slaganje s tvrdnjom kako je tako organizirana nastava odlična.

Dobiveni rezultati istraživanja provjereni su Kolmogorov-Smirnovljevim testom za utvrđivanje normalnosti podataka. Kako je iskazana normalna distribucija podataka, u daljnjoj analizi korišten je t-test za nezavisne uzorke. Tablica 3 prikazuje rezultate t-testa za nezavisne uzorke koji je rađen s ciljem identifikacije značajnosti razlika u odgovorima ispitanih učitelja i studenata. Razlika se smatra statistički značajnom ukoliko je $\mathrm{p}<0,05$.

Tablica 3. Rezultati t-testa usporedbe istovjetnih varijabli za učitelje i studente (M-aritmetička sredina; t-vrijednost t-testa; df-stupnjevi slobode; p-nivo značajnosti)

\begin{tabular}{lccccc}
\hline \multicolumn{1}{c}{ Varijable } & $\begin{array}{c}\text { M } \\
\text { (učitelji) }\end{array}$ & M (studenti) & $\mathbf{t}$ & $\mathbf{d f}$ & $\mathbf{p ~}$ \\
\hline $\begin{array}{l}\text { Prelazak s redovne nastave na } \\
\text { nastavu na daljinu bio mi je }\end{array}$ & 3,31 & 2,56 & 4,14 & 327 & $<\mathbf{0 , 0 1}$ \\
težak. & & & & & \\
$\begin{array}{l}\text { Potrebno mi je više vremena } \\
\text { tjedno u pripremi za nastavu na } \\
\text { daljinu u odnosu na redovnu } \\
\text { nastavu. }\end{array}$ & 4,22 & 3,98 & 1,49 & 327 & 0,14 \\
$\begin{array}{l}\text { Za kvalitetno odvijanje nastave } \\
\text { na daljinu bitna je dobra } \\
\text { internetska veza. }\end{array}$ & 4,49 & 4,77 & $-2,18$ & 327 & $\mathbf{0 , 0 3}$ \\
$\begin{array}{l}\text { Tijekom nastave na daljinu } \\
\text { javljaju se tehnički problemi. }\end{array}$ & 3,69 & 4,18 & $-2,99$ & 327 & $<\mathbf{0 , 0 1}$ \\
$\begin{array}{l}\text { Uvođenjem nastave na daljinu } \\
\text { samostalno sam se educirala/ } \\
\text { educirao o korištenju i primjeni } \\
\text { različitih digitalnih alata. }\end{array}$ & 4,32 & 4,08 & 1,62 & 327 & 0,11 \\
$\begin{array}{l}\text { Nastava prirode i društva } \\
\text { organizirana na televiziji je } \\
\text { odlična. }\end{array}$ & 2,64 & 2,97 & $-2,12$ & 327 & 0,03 \\
\hline
\end{tabular}

Iz tablice 3. može se iščitati kako postoji statistički značajna razlika u odgovorima učitelja i studenata o težini prelaska s redovne nastave na nastavu na daljinu $(\mathrm{p}=0.00)$ što ukazuje kako je učiteljima prelazak s redovne nastave na nastavu na daljinu bio statistički značajno teži. Rezultat t-testa ne potvrđuje hipotezu H1. Razlozi ovakve percepcije težine prelaska s redovne na online nastavu svakako mogu biti u stupnju razvijenosti digitalne kompetencije učitelja. Kako je već spomenuto 22,8 \% ispitanih učitelja ima preko 26 godina radnog staža pa pripadaju skupini koja nije imala formalnu edukaciju iz informatike 
tijekom školovanja i studija, a sve potrebne vještine i znanja stjecali su na dodatnim edukacijama tijekom radnoga vijeka. Uočeno je kako ne postoji statistički značajna razlika s obzirom na radno iskustvo, te vrstu škole u kojoj ispitanici rade što korelira s rezultatima istraživanja Bulić i Novoselić (2016). Kako su provedena istraživanja (Bulić i Novoselić, 2016; Kostović-Vranješ, 2011; Kostović-Vranješ i sur., 2015) ukazala na nesklonost učitelja prirode i biologije prema primjeni IKT-a u nastavnom procesu te potrebu proširivanja njihovih IKT kompetencija, vjerojatno je to jedan od razloga zbog kojeg učitelji osjećaju težim prelazak s redovne na online nastavu. Može se pretpostaviti kako je tako loša razina integracije računalnih sadržaja u nastavnom procesu u korelaciji s nedostatkom digitalnih kompetencija učitelja (Krumsvik, 2014). Isto zaključuju Lukša i Vuk (2014). Kostović-Vranješ i sur. (2015) ukazuju na nedostatnu računalnu osposobljenost učitelja biologije što dovodi do niske razine primjene IKT-a u nastavi, a tijekom online nastave koja se provodila $\mathrm{u}$ školama 2020. godine računalo im je bilo primarni alat za komunikaciju s učenicima, dijeljenje i pregledavanje nastavnih sadržaja. S druge strane, studentima prijelaz na online nastavu nije težak kao učiteljima jer im je IKT blizak, a tijekom formalnoga obrazovanja svi studenti su imali nastavni predmet informatiku. Pojedini studenti koji su sudjelovali u istraživanju uz razrednu nastavu studiraju primjenu IKT-a u ranom učenju i poučavanju (Modul 2).

Za varijablu o potrebnom tjednom vremenu u pripremi za nastavu na daljinu u odnosu na redovnu nastavu nije utvrđeno postojanje statistički značajne razlike $(\mathrm{p}=0,14)$ što ukazuje kako je hipoteza $\mathbf{H 2}$ potvrđena. Pretpostavlja se kako su učitelji odgovorno pristupili nastavi na daljinu te su samostalno pripremali potrebne sadržaje za rad ili su koristili gotove materijale izdavačkih kuća ili materijale pripremljene od strane Ministarstva. Oni koji su se kvalitetno i samostalno pripremali za redovnu nastavu nastavili su isti obrazac ponašanja i u nastavi na daljinu. Studenti su tijekom redovne nastave samostalno pripremali seminare ili vježbe prema utvrđenom rasporedu, a takav obrazac ponašanja se nastavio i tijekom nastave na daljinu te stoga ne iskazuju razliku u tjedno utrošenom vremenu za pripreme.

Hipoteza $\mathbf{H 3}$ je potvrđena, nije identificirana statistički značajna razlika u odgovorima učitelja i studenata o samostalnoj edukaciji o korištenju i primjeni različitih digitalnih alata $(\mathrm{p}=0,11)$. Jedni i drugi su se samostalno educirali jer su dovedeni u situaciju da koriste nove digitalne alate i platforme koje prije nisu koristili. Tijekom nastave na daljinu učitelji su koristili različite sustave poput Edmodo, Yammer, te druge alate za komunikaciju, razmjenu informacija i učenje. Online nastava pratila se i na mrežnim stranicama Škole za život (https://skolazazivot.hr/video-lekcije/), YouTube kanalu i televizijskim programima HRT3 i SPTV. Studenti Filozofskog fakulteta online nastavu pratili su na Google Hangouts Meet. Upravo je prelazak na novi način rada u novom digitalnom okružju implicirao brzo samoeduciranje o novim alatima kojima su 
se trebali služiti jedni i drugi te stoga nema statistički značajne razlike među ispitanicima.

Rezultati t-testa ne potvrđuju hipotezu H4. Naime, pokazalo se kako studenti procjenjuju statistički značajno više važnom postojanje dobre internetske veze za kvalitetno odvijanje nastave na daljinu u odnosu na učitelje. Studenti u većoj mjeri iskazuju da se tijekom nastave na daljinu javljaju tehnički problemi. Zasigurno je kako je internetska veza presudan čimbenik odvijanja nastave na daljinu. Međutim kako većina učitelja razredne nastave nije održavala nastavu u realnom vremenu sa svojim učenicima već su učenici pratili nastavu na HRT3, a učitelji su im slali prezentacije, nastavne listiće i razne didaktičke materijale za rad to su mogli učiniti u bilo koje vrijeme dana. Nasuprot tome, na Fakultetu se nastava odvijala online u realnom vremenu i studentima je jako važna internetska veza za kvalitetno praćenje predavanja i same nastave.

Hipoteza $\mathbf{H 5}$ nije potvrđena jer je t-testom utvrđeno postojanje statistički značajne razlike $(p=0,03)$ za varijablu o nastavi prirode i društva organiziranoj na televiziji u odgovorima učitelja i studenata odnosno pokazalo se da studenti iskazuju pozitivnije stavove o spomenutoj nastavi. Možebitni razlog takve percepcije nastave prirode i društva na televiziji ima uzrok u tome što učitelji, kao stručnjaci koji dobro poznaju kurikulum nastavnog predmeta, mogu detaljnije i objektivnije sagledati emitirane sadržaje na televiziji te uvidjeti neslaganja s Godišnjim izvedbenim kurikulumom. Tijekom nastave na daljinu moglo se uočiti kako pojedini nastavni sati traju tek dvije ili tri minute, a tema im je takva da je ne mogu povezati niti s jednom nastavnom jedinicom. Također, učitelji su uočavali određene materijalne greške koje su se javljale tijekom nastave na televiziji, npr. tijekom sati prirode i društva kada učiteljica u ruci drži puževu kućicu, a djeci govori kako je to školjka. Učitelji također uočavaju i druge metodičke nedostatke poput lošega plana ploče, ne brisanja plana ploče nakon nastavnog sata, nepravilne demonstracije ili izvođenja pokusa što je studentima teže uočiti jer još nemaju dovoljna metodička znanja. PowerPoint prezentacije koje su učiteljice prezentirale tijekom nastave, pa tako i tijekom sati prirode i društva nisu bile ujednačene. Učeničku pažnju ometali su logotipi na dnu PPT prezentacija, te logotip u gornjem desnom uglu, a sami slajdovi ponekad nisu bili metodički dobro oblikovani (font je ponekad bio presitan, cijeli tekst se pojavljivao odjednom, a ne postupno, fotografije i slike su bile premale i ponekad upitne kvalitete, kamera nije pratila točno ono o čemu učiteljica priča,...). Upravo su to razlozi zašto učitelji lošije procjenjuju kvalitetu nastave prirode i društva na televiziji u odnosu na studente.

Zabrinjavajući podatak treba biti da gotovo $40 \%$ učitelja primjećuje kako domaće zadaće iz prirode i društva koje trebaju pisati učenici piše netko drugi umjesto njih tijekom nastave na daljinu (slika 2). 


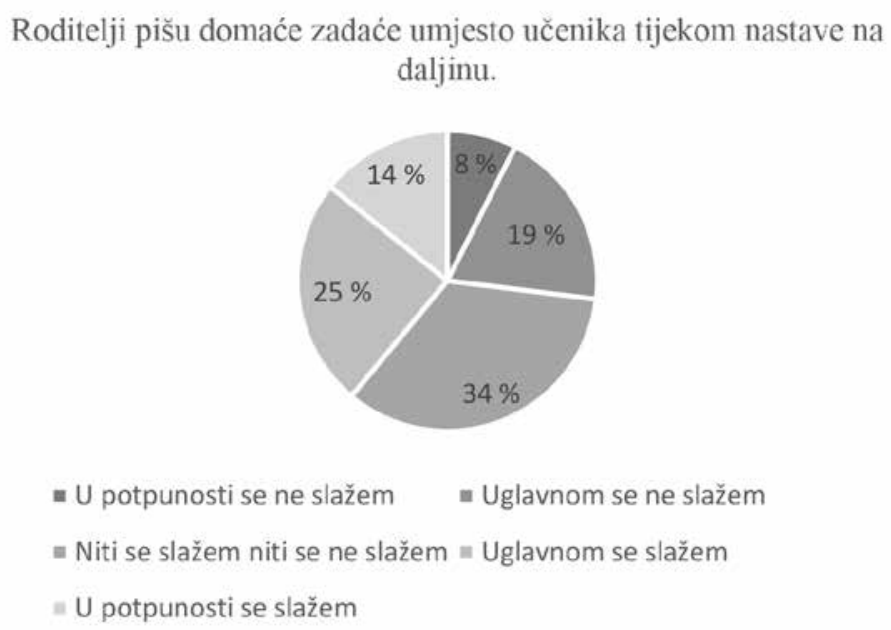

Slika 2. Odgovori učitelja na česticu „Roditelji pišu domaće zadaće umjesto učenika tijekom nastave na daljinu." prikazani u postocima

To nije nikako opravdano niti dobro jer domaća zadaća treba omogućiti učenicima procesuiranje informacija dobivenih tijekom nastave (Painter, 2003) te im pomaže u ostvarivanju traženih odgojno-obrazovnih ishoda bilo kojeg nastavnoga predmeta pa tako i prirode i društva. Ako dijete nije pisalo domaću zadaću postavlja se pitanje je li ostvarilo traženi ishod učenja. Roditelji, radeći umjesto vlastite djece nisu im učinili uslugu već ih zakinuli za razmišljanje o zadatku i traženje rješenja te zaključivanje. Istraživanje Bulić i Kostović-Vranješ (2019) o samoodgovornosti učenika u pisanju domaćih zadaća tijekom e-učenja (potpuno online nastave) pokazuje kako je učenicima rad u digitalnom okružju bio motivacijski faktor i pisali su domaće zadaće. Također je odgovornost u pisanju domaćih zadaća veća kod učenika mlađe životne dobi u odnosu na učenike 7. i 8. razreda. Pažljivom kvalitativnom analizom autorice su utvrdile da su i slabije aktivni učenici tijekom rada u online nastavi redovito izvršavali svoje domaće zadaće.

S obzirom na to da su na kraju anketnog upitnika obje skupine ispitanika imale pitanja otvorenog tipa napravljena je kvalitativna analiza njihovih odgovora. Kao prednost nastave na daljinu $56 \%$ studenata je istaknulo vremensku fleksibilnost jer im ovakva nastava na daljinu omogućava kvalitetnije odrađivanje zadataka kao i više vremena za obavljanje istih: „Budući da imam više vremena, mogu kvalitetnije odraditi zadatke.“, „Više vremena za obaviti zadatke.“. Nadalje, ispitanici ističu kako u nastavi na daljinu bolje mogu organizirati svoje vrijeme za učenje: „Prednost nastave na daljinu svakako je u tome što studenti imaju više vremena za organizaciju svojih obaveza.“, „Student sam organizira svoje vrijeme te odrađuje zadatke kada je najproduktivniji.“, 
„Samostalno određivanje vremena za učenje.“. Studenti također ističu kako ne gube vrijeme na put do i od fakulteta: „Ušteda vremena jer ne moramo putovati do fakulteta (meni konkretno treba svaki dan oko pola sata vožnje autom do fakulteta i pola sata natrag do kuće).“, „Prednost je što se ne gubi vrijeme na prijevoz.“, „Jedna od velikih ušteda je na vremenu putovanja do i od zgrade fakulteta.". Uz vremensku fleksibilnost, studenti kao prednost navode i prostornu fleksibilnost (42\%) jer ističu mogućnost praćenja nastave bilo gdje (s različitih lokacija, ponajprije u udobnosti vlastitoga doma): „Udobnost slušanja predavanja od kuće.“, „Možemo pratiti nastavu odakle želimo (u ambijentu koji nam najviše odgovara)“. Navedeni rezultati koreliraju s rezultatima istraživanja Jukić (2017) provedenom na uzorku od 1318 studenata hrvatskih sveučilišta u kojem su ispitani studenti kao prednost online učenja prepoznali fleksibilnost po pitanju mjesta učenja. Studenti online nastavu smatraju pristupačnom jer nadilazi fizičku udaljenost između profesora i studenta i studentima daje mogućnost pristupa nastavnim materijalima u bilo koje vrijeme.

Kao nedostatak nastave na daljinu $50 \%$ studenata ističe nedostatak fizičkog kontakta (licem u lice) i nedostatak interakcije i socijalnog kontakta s profesorima i ostalim studentima. Studenti smatraju kako je komunikacija tijekom online nastave lošija u odnosu na redovnu nastavu. Ovaj rezultat korelira $\mathrm{s}$ istraživanjem McBrien i suradnika (2009) u kojem se pokazalo da za ispitane studente element osobnoga kontakta s profesorom i ostalim studentima koji nedostaje u online nastavi smanjuje njihov osjećaj pripadnosti kao i osjećaj sudjelovanja u nastavi. Do rezultata da studenti komunikaciju u nastavi na daljinu procjenjuju lošijom u odnosu na redovnu nastavu došli su i Gabrilo i Rodek (2009) u istraživanju kojim su se ispitivali stavovi studenata doktorskog studija Kineziološkog fakulteta u Splitu o učenju putem interneta. Povezano s nedostatkom fizičkog kontakta, ispitani studenti ističu kako je profesorima u nastavi na daljinu otežano praćenje studentove aktivnosti i sudjelovanja na nastavi: „Profesori ne mogu pratiti koliko tko sudjeluje na predavanju.“, „Može se upaliti predavanje i ne slušati.“, „Ne trebamo sudjelovati u nastavi.“, „U nastavi na daljinu mnogi uopće ne sudjeluju." Studenti (42\%) kao nedostatak nastave na daljinu navode povećanje količine zadataka u odnosu na nastavu na fakultetu: „Nedostatci su više zadataka nego kod klasične nastave“, „Nedostatak nastave na daljinu je što profesori zadaju 70 \% više zadataka nego prije“, „Profesori misle da imamo više vremena, a zapravo vremena je jednako kao i ranije jer predavanja imamo isto kao i prije. Razlika je u tome što imamo više zadataka“. U istraživanju Smidt i sur. (2014) o stavovima studenata o nastavi na daljinu studenti smatraju da ovakav oblik nastave ima veliko radno opterećenje i zahtijeva od studenata veću razinu autonomije u savladavanju gradiva kao i da za razliku od nastave licem u lice gdje bi studentima zadatci bili zadani samo na dan održavanja nastave, u nastavi na daljinu studenti bi dobivali zadatke tijekom cijelog tjedna neovisno o održavanju nastave. 
Tehničke poteškoće s kojima su se susretali tijekom nastave na daljinu navodi kao nedostatak $13 \%$ ispitanih studenata, a do njih najčešće dolazi zbog problema s internetskom vezom. Svakako je nedostatak nastave na daljinu i dugotrajno sjedenje studenata pred računalom: „Više vremena provođenja pred laptopom što utječe na naše zdravlje“, „Pred ekranom doslovno provodimo dane od jutra do sutra i to od ponedjeljka do nedjelje čak.".

Kao nedostatak nastave prirode i društva organizirane na televiziji $36 \%$ ispitanih studenata (koji su pratili nastavu prirode i društva u sklopu kolegija Metodika nastave prirode i društva) ističe kratko trajanje nastavnih sati, od kojih su pojedini nastavni sati trajali manje od pet minuta. Studenti smatraju kako zbog navedenoga nedostaje vremena za objašnjavanje bitnih pojmova te kako se u kratkom vremenu ne mogu ostvariti svi potrebni odgojno-obrazovni ishodi. Kao nedostatak nastave na daljinu organizirane na televiziji $31 \%$ ispitanika ističe nemogućnost postizanja interakcije i komunikacije na relaciji učitelj - učenik i učenik - učenik. Studenti ističu kako se zbog navedenoga ne može dobiti povratna informacija učenika niti se pratiti njihovo razumijevanje sadržaja. Kao prednost nastave prirode i društva organizirane na televiziji naveli su kako učenici na ovakav način ipak imaju kontinuitet nastave te da barem prate sadržaje svoga razreda.

Učitelji (29\%), kao prednost nastave na daljinu ističu digitalizaciju jer je ovakav oblik nastave utjecao na razvoj njihovih, ali i učeničkih digitalnih kompetencija i informatičko opismenjavanje: „Jačanje informatičke pismenosti.“, „Bolja informatička opismenjenost.“, „Aktivnije korištenje IKT-a.“, „Osobno educiranje i korištenje digitalne tehnologije.“, „Digitalno opismenjavanje učenika.“. Učitelji ističu da su u ovakvome načinu rada otkrili te počeli koristiti različite digitalne alate, materijale i sadržaje: „Otkrila sam nove alate i aplikacije za rad.“, „Situacija je dovela do mogućnosti korištenja brojnih programa koji su do sada radi skupoće bili nedostupni većini učitelja, tako da je nastava zanimljivija“, „To što ljudi stvaraju i dijele toliko materijala koje ćemo biti i u budućnosti u mogućnosti koristiti.“. Ovaj rezultat korelira s rezultatima istraživanja Tomaš i Mladenovski (2016) koje pokazuje da učitelji imaju pozitivne stavove prema primjeni IKT-a u nastavi, da su spremni i motivirani mijenjati način poučavanja i uključiti IKT u nastavu. Također, učitelji smatraju da se uključivanjem IKT-a u nastavi ostvaruje kreativnije i kvalitetnije poučavanje.

Vremensku fleksibilnost, kao prednost, prepoznaje $28 \%$ učitelja: „Učenici imaju mogućnost organizirati svoje vrijeme i rasporediti poslove.“, „To što je puno fleksibilnija nego klasična nastava. U smislu da učenik ne mora nužno sjediti od 08 - 14 h,“, „Vrijeme rješavanja zadataka nije ograničeno što mnogim učenicima odgovara.“, „Dijete ima mogućnost u svom ritmu raditi zadatke, može si nekoliko puta ponoviti upute.“, „Učenici imaju više vremena za kreativne zadatke pa im se s guštom posvete, ulože više truda i vremena pa nastanu zapanjujući radovi.“. 
Kao nedostatak nastave na daljinu, $62 \%$ učitelja istaknulo je nedostatak direktnoga kontakta, socijalizacije i interakcije s učenicima: „Nedostatak neposrednog kontakta i trenutne povratne informacije.“, „Nema svakodnevne "žive” riječi, te interakcije sa učenicima.“, „Nedostatak direktne komunikacije s učenicima, sve se odvija uz pomoć roditelja budući da imam 1. razred.“. Ispitanici također nastavu i atmosferu u učionici ističu kao nezamjenjivu: „Ljudski kontakt, socijalna interakcija, direktno prenošenje znanja od čovjeka do čovjeka je nezamjenjivo ičim.“, „Interakcija preko ekrana je nedostatna jer djeci nedostaje komuniciranje uživo, druženje i interakcija s vršnjacima, ali i s učiteljicama i učiteljima.“, „Nedostatak živog kontakta s djecom; živa riječ je ipak ono što čini naš posao i nikakva tehnika ga ne može zamijeniti. Ovo sve je samo privid nastave; nema do učitelja, učionice, ploče i krede“.

$23 \%$ učitelja kao nedostatak nastave prirode i društva organizirane na televiziji ističe teškoće u vrednovanju i ocjenjivanju. Iako su učenici pratili nastavu na televiziji redovito su dobivali domaće zadaće koje su trebali riješiti i različitim alatima slati svojim učiteljima na pregledavanje. Učitelji u odgovorima otvorenog tipa dovode u pitanje samu vjerodostojnost učeničkih radova: „Objektivnost rada/vrednovanja učenika., neobjektivna i nerealna povratna informacija s učenika.“, „Nedostatak nastave na daljinu je taj da većinu postavljenih zadataka može umjesto učenika odraditi netko drugi.“, „Nepouzdanost rezultata, je li učenik prepisao ili samostalno radio.“, „Konstantan osjećaj da nemam sve aspekte poučavanja i vrednovanja pod kontrolom.“, „Ništa nisu naučili, prepisuju, roditelji pišu radove, mi to vidimo ali nemamo dokaza.... Najlošiji učenici ispadaju sada s najboljim domaćim radovima." Ispitani učitelji također nedostatak vide $u$ prečestom uplitanju roditelja i rješavanju zadataka umjesto djece: „Pojedini roditelji rješavaju domaće zadaće. Čak pišu svojim rukopisom. Unatoč upozorenjima to ne prestaje. Radi se o jednostavnim zadatcima iz učenikove radne bilježnice što i inače rješavamo u školi. A o crtanju umjesto djece neću ni pisati. Jednostavno ne znam kako ću pojedinu djecu ocijeniti.“, „Neki roditelji rade zadaće umjesto svoje djece. Nemoguće je objektivno i realno ocijeniti znanje djece.“, „Roditelji pišu većinu zadaće.“, „Rezultati nisu realni jer se roditelji previše (i nepotrebno) angažiraju u realizacija dječjih radova.“, „Roditelji rade umjesto učenika, poslani zadatci ne pokazuju realno znanje i ne dobivam realnu sliku o tome koliko je gradivo usvojeno.“. Učitelji kao prednost nastave prirode i društva organizirane na televiziji, slično kao i studenti, navode to što je uopće više-manje uspješno organiziran ovakav oblik nastave na televiziji te da djeca imaju medij putem kojega mogu pratiti nastavu svoga razreda. 


\section{ZAKLJUČAK}

U izazovnom pandemijskom vremenu, RH je uspjela odgojno-obrazovni sustav preokrenuti u izuzetno kratkom vremenu. Općenito govoreći, to je bio vrlo zahtjevan posao koji je većinom uspješno odrađen. Promatrajući nastavu na daljinu koja je bila organizirana u izuzetno kratkom vremenu, a obuhvatila je kompletnu odgojno-obrazovnu vertikalu u svim odgojno-obrazovnim ciklusima uviđa se potreba za trajnim usavršavanjem i proširivanjem kompetencijskog profila učitelja te mijenjanjem pristupa stjecanju kompetencija budućih učitelja, studenta. Ovo iskustvo nastave na daljinu treba postati sastavni dio metodike nastave prirode i društva, ali i ostalih metodika nastave, kako bi studenti s fakulteta izišli s kvalitetnim kompetencijskim profilom koji je preduvjet kvalitetnom radu u razredu. U situacijama izvanrednih okolnosti nastava na daljinu pokazala se iznimno važnom, a nastavom organiziranom na televiziji učenicima se zasigurno olakšao prijelaz $\mathrm{s}$ redovne nastave na ovakav oblik. Izvanredne situacije poput trenutne pandemije jasno pokazuju kako je neophodno imati gotove, pažljivo oblikovane didaktičko-metodičke materijale iz svih nastavnih predmeta pa tako i prirode i društva.

Istraživanje je pokazalo kako učitelji percipiraju prelazak s redovne nastave na nastavu na daljinu statistički značajno težim u odnosu na studente, a jedni i drugi jednako vremena troše na pripremanje za online nastavu kao što su trošili i prije u redovnoj nastavi. Učitelji i studenti su se samostalno educirali u nastaloj situaciji kada su brzo trebali početi koristiti nove alate koje ranije nisu koristili. Studenti, za razliku od učitelja, statistički značajno više važnom procjenjuju postojanje dobre internetske veze u odnosu na učitelje. Iako su ispitani učitelji i studenti prepoznali prednosti nastave na daljinu poput vremenske ili prostorne fleksibilnosti, ipak su istaknuli i njene nedostatke od kojih je najveći nedostatak direktnoga kontakta. Kako bi se premostio jaz fizičke razdvojenosti i izbjegao osjećaj izoliranosti, svakako bi trebalo s učenicima ostvarivati što češći kontakt u realnome vremenu, a navedeno bi se moglo postići organizacijom sastanaka putem videokomunikacijskih alata. S obzirom na to da nastava na daljinu zahtjeva veću autonomiju, samostalnost i rad učenika, posebno bi učitelji prilikom zadavanja domaćih zadaća trebali regulirati količinu zadataka za učenike. Stavovi studenata i učitelja o nastavi na televiziji također se razlikuju jer studenti iskazuju pozitivnije stavove o nastavi na televiziji.

Može se reći kako je izazovu nastave na daljinu u uvjetima pandemije uspješno odgovoreno zahvaljujući predanom zajedničkom radu učitelja i njihovih učenika. Čak i nakon prolaska aktualne zdravstvene krize, mogu se u odgojno-obrazovnom sustavu $\mathrm{RH}$, dugoročno ostvariti promjene temeljene na ovom iskustvu nastave na daljinu. 


\section{LITERATURA}

Allen, E.I, Seaman, J., Lederman, D. i Jaschik, S. (2012). Conflicted: Faculty and Online Education. Babson Survey Research Group and Quahog Research Group, LLC. https://files.eric.ed.gov/fulltext/ED535214.pdf.

Allen, E.I. i Seaman, J. (2013). Changing Course: Ten Years of Tracking Online Education in the United States. Babson Survey Research Group and Quahog Research Group, LLC.

Annetta, L. i Shymansky, A.J. (2008). A Comparison of Rural Elementary School Teacher Attitudes Toward Three Modes of Distance Education for Science Professional Development. Journal of Science Teacher Education, 19(3), 255267. https://doi.org/10.1007/s10972-008-9089-4

Boras, M. (2009). Suvremeni pristupi nastavi prirode i društva. Život i škola: časopis za teoriju i praksu odgoja i obrazovanja, 55(21), 40-49. https://hrcak.srce.hr/37079

Budić, H. i Hak, M. (2014). Primjena suvremene obrazovne tehnologije u nastavi. International conference „Vallis aurea“. (pp. 65-73). Repository of Polytechnic in Pozega. https://urn.nsk.hr/urn:nbn:hr:112:363339

Bulić, M. i Novoselić, D. (2016). Kompetencije učitelja biologije za izradu računalnih sadržaja i uporabu informacijsko-komunikacijskih tehnologija. Magistra Iadertina, 11(1), 89-104. https://hrcak.srce.hr/177643

Bulić, M., Jelaska I., i Mandić Jelaska P. (2017). Utjecaj e-učenja na usvojenost ishoda učenja u nastavi Prirode i Biologije. Croatian Journal of Education, 19(2), 447477. https://doi.org/10.15516/cje.v19i2.2230

Bulić, M. (2018). Sustavi e-učenja u promicanju obrazovanja za zdrav i održiv život. [doctoral dissertation, University of Split]. Faculty of Science in Split Repository. https://dr.nsk.hr/islandora/object/pmfst\%3A541/datastream/PDF/view

Bulić, M., i Kostović-Vranješ, V. (2019). Utjecaj e-učenja na samoodgovornost učenika pri izvršavanju domaćih zadaća. Školski vjesnik, 68(1), 112-126. https://hrcak. srce.hr/230624

CARNet (2020). Europski okvir digitalnih kompetencija za obrazovatelje (DigCompEdu). Hrvatska akademska i istraživačka mreža. https://www.e-skole. $\mathrm{hr} /$ wp-content/uploads/2020/04/CARNET_digitalne_kompetencije_2020.pdf

Ćukušić, M. i Jadrić, M. (2012). e-učenje: koncept i primjena. Školska knjiga.

Gabrilo, G. i Rodek, J. (2009). Učenje putem interneta - mišljenja i stavovi studenata. Školski vjesnik, 58(3), 281-299. https://hrcak.srce.hr/82600

Gökbulut, B. (2020). Distance Education Students' Opinions on Distance Education. In M. Durnali, \& I. Limon (Eds.), Enriching Teaching and Learning Environments With Contemporary Technologies (pp. 138-152). IGI Global.

Hutinski, Ž. i Aurer, B. (2009). Informacijska i komunikacijska tehnologija u obrazovanju: stanje i perspektive. Informatologia, 42(4), 265-272. https://hrcak.srce. $\mathrm{hr} / 42347$ 
Jukić, D. (2017). Tehnička pripremljenost i motiviranost studenata hrvatskih sveučilišta za online oblik nastave. Život i škola, 63(1), 93-102. https://hrcak.srce.hr/193882

Kalamković, S., Halaši, T. i Kalamković, M. (2013). Učenje na daljinu primijenjeno u nastavi osnovne škole. Croatian Journal of Education, 15(Sp.Ed.3), 251-269. https://hrcak.srce.hr/111354

Kostović-Vranješ, V. (2011). Information-communication technologies in biology teaching: present states and possibilities. In J. Milat (Ed.), Digital technologies and new forms of learning (pp. 181-189). Faculty of philosophy University of Split, Faculty of education University of Chieti-Pescara.

Kostović-Vranješ, V. (2015). Metodika nastave predmeta prirodoslovnog područja. Školska knjiga.

Kostović-Vranješ V., Bulić, M. i Novoselić, D. (2016). Kompetencije učitelja biologije za primjenu informacijsko-komunikacijskih tehnologija u nastavnom procesu. Zbornik radova Filozofskog fakulteta u Splitu, (6-7), 15-26. https://hrcak.srce. $\mathrm{hr} / 154574$

Krumsvik, R. J. (2014). Teacher educators' digital competence. Scandinavian Journal of Educational Research, 58(3), 269-280. https://doi.org/10.1080/00313831.2012 .726273

Li, R., Bunk, J. i Smidt, E. (2017). Understanding Faculty and Student Attitudes about Distance Education: The Importance of Excitement and Fear. In M. Northcote, K.P. Gosselin (Eds.), Handbook of Research on Humanizing the Distance Learning Experience (pp. 410-435). IGI Global.

McBrien, J.L., Jones, P. i Cheng, R. (2009). Virtual Spaces: Employing a Synchronous Online Classroom to Facilitate Student Engagement in Online Learning. The International Review of Research in Open and Distributed Learning, 10(3), 1-17. https://files.eric.ed.gov/fulltext/EJ847763.pdf

Ministarstvo znanosti, obrazovanja i športa (2011). Nacionalni okvirni kurikulum za predškolski odgoj, opće obvezno i srednjoškolsko obrazovanje. Republika Hrvatska, Ministarstvo znanosti, obrazovanja i športa. http://mzos.hr/datoteke/ Nacionalni_okvirni_kurikulum.pdf

Ministarstvo znanosti i obrazovanja (2020). Dodatne upute vezano uz obustavu nastave na visokim učilištima. Republika Hrvatska, Ministarstvo znanosti i obrazovanja. https://mzo.gov.hr/UserDocsImages/dokumenti/Vijesti/2020/Dodatne\%20 upute $\% 20$ vezano $\% 20$ uz $\% 20$ obustavu $\% 20$ nastave $\% 20$ na $\% 20$ visokim $\% 20$ ucilistima\%20-\%2013.\%203.\%202020..pdf

Ministarstvo znanosti i obrazovanja (2020). Uputa svim osnovnim i srednjim školama vezano uz nastavak organizacije nastave na daljinu. Republika Hrvatska, Ministarstvo znanosti i obrazovanja. https://mzo.gov.hr/vijesti/uputa-svim-osnovnim-i-srednjim-skolama-vezano-uz-nastavak-organizacije-nastave-na-dalji$\mathrm{nu} / 3592$

Ministarstvo znanosti i obrazovanja (2020). Upute za vrednovanje i ocjenjivanje tijekom nastavena daljinu. Republika Hrvatska, Ministarstvo znanosti i obrazovanja. https:// 
mzo.gov.hr/UserDocsImages/dokumenti/Obrazovanje/Upute-za-vrednovanje/ Upute\%20za\%20vrednovanje\%20i\%20ocjenjivanje\%20tijekom\%20nastave $\% 20$ na\%20daljinu.pdf?fbclid=IwAR3hTiwCR87KUwysOJ0yvhxHrI42u7oTsh7ReG2cza_pVp53tZJR14vd4b0

Nadrljanski, Đ. (2006). Informatička pismenost i informatizacija obrazovanja. Informatologia, 39(4), 262-266. https://hrcak.srce.hr/9254

Painter, L. i Maley, A. (2003). Homework. Kogan Page Publishers.

Pejić Papak, P. i Grubišić Krmpotić, H. (2016). Poučavanje primjenom suvremene tehnologije u obrazovanju. Život i škola, 62(3), 153-162. https://hrcak.srce.hr/176919

Simonson, M., \& Berg, G.A. (2016). Distance learning. Encyclopædia Britannica, inc. https://www.britannica.com/topic/distance-learning.

Smidt, E., Bunk, J., McGrory, B., Li, R., i Gatenby T. (2014). Student Attitudes about Distance Education: Focusing on Context and Effective Practices. The IAFOR Journal of education, 2(1), 40-64. https://files.eric.ed.gov/fulltext/EJ1080350.pdf.

Tinio, V.L. (2003). ICT in Education. E-ASEAN Task Force.

Tomaš, S. i Mladenovski, A. (2016). The implementation of information and communication technologies in education. In R. Jukić, K. Bogatić, S. Gazibara, S. Pejaković, S. Simel \& A. Nagy Varga (Eds.), Zbornik znanstvenih radova s Međunarodne znanstvene konferencije Globalne i lokalne perspektive pedagogije (pp. 291-300). Filozofski fakultet Osijek.

Zenović, I. i Bagarić, I. (2014). Trendovi u otvorenom učenju na daljinu u svetu i kod nas. Sinteza, 379-384. http://portal.sinteza.singidunum.ac.rs/Media/files/2014/379-384.pdf. 